\title{
A note on Family Lamiaceae in Todgarh-Raoli Wildlife Sanctuary, with Addition of Two Species for Flora of Rajasthan
}

\author{
${ }^{*} \mathrm{C}$. S. Purohit, ${ }^{2}$ Komal Jain and ${ }^{3}$ Merushikha \\ ${ }^{1}$ Botanical Survey of India, Andaman \& Nicobar Regional Centre, Port Blair, India \\ 2Department of Botany, Mahila P.G. Mahavidhyalaya, Jodhpur, Rajasthan, India \\ ${ }^{3}$ Department of Botany, Rajasthan University, Jaipur, Rajasthan, India \\ *Corresponding author e-mail address: chandansinghpurohit@yahoo.com
}

\section{ABSTRACT}

Present paper deals with 16 species belonging to 9 genera of family Lamiaceae collected from this sanctuary. Out of these, two species Ocimum basilicum L. var. pilosum (Willd.) Bentham and Orthosiphon aristatus (Blume) Miq. are reported first time and addition for flora of Rajasthan. Five species are reported first time and addition for flora of Aravalli range. Seven genera Anisochilus, Anisomeles, Hyptis, Lavandula, Nepeta, Orthosiphon and Salvia are first time report and generic addition for flora of Todgarh-Raoli wildlife sanctuary and 14 plant species are addition for flora of Todgarh-Raoli wildlife sanctuary.

Keywords: Addition, Lamiaceae, Rajasthan, Aravalli, Todgarh-Raoli wildlife sanctuary

\section{INTRODUCTION}

India is known for rich repository of biological wealth having more than 17,500 wild plant species and of these 4,000 species have medicinal values and it play an important role in human life. Plants were introduced in this region both adventitiously and intentionally for purpose of food, fodder, soil conservation, medicine, packing material, forage and manure. Several plant species are gradually becoming rare in their original habitats. This is due to uncontrolled clearing of forests for cultivation and for developmental projects taking place in the entire range of distribution in the country or any state and selection of areas rich in plant diversity and declaring these as Biosphere Reserves, National Parks and Wild Life Sanctuaries in different parts of the country, as the "Todgarh-Raoli Wildlife Sanctuary"can save the depleting plant diversity in the Rajasthan State.

\section{STUDY AREA}

It is situated in most fragile ecosystem of Aravallis "Todgarh-Raoli Wildlife Sanctaury" is just $110 \mathrm{kms}$ in the southwest of famous city "Ajmer". Geographically this sanctuary is situated between $73^{\circ} 40^{\prime}-74^{\circ} 10^{\prime}$ east longitudes and $25^{\circ} 20^{\prime}-26^{\circ} 0^{\prime}$ north latitudes, covers an area of $495.27 \mathrm{~km}^{2}$ and extended in three districts viz. Rajsamand, Pali and Ajmer in the south-western part of Rajasthan State. It is one of the protected areas expressing full range of habitat of Aravalli ecosystem. It is important from Bio-geographical point of view, since it forms one of the patches of Dhok and Salar forests. It has exceptional diversity and interspersion of habitat which includes areas of Dhok, Salar, dryland, seasonal streams, cascading mountains and newly formed sand dunes, formed on western hill aspects and fine grooves of mixed wood lands. This sanctuary makes an ecotone between hilly forests of Aravallis and Thar dessert situated in the north-west. 
The hills of this sanctuary acts like a barrier, checking eastward extension of desert.

\section{MATERIAL AND METHODS}

While working on the floristic diversity of the Todgarh-Raoli Wildlife Sanctuary (Rajasthan) during 2015 to 2019, author collected 16 plant samples of family Lamiaceae from different locations of this sanctuary. These collected herbarium samples deposited at Botanical Survey of India, Jodhpur (BSJO). After critical study, scrutiny of literature (Hooker, 1885; Blatter \& Hallberg, 1920; Mukerjee, 1940; Sharma \& Tiagi, 1979; Bhandari, 1990; Shetty \& Singh, 1991; Singh, 1998; Singh, 2001; Tiagi \& Aery, 2007; Otaghvari et al., 2015) and herbaria (BSJO, BSA, RUBL, JAC, BLAT, DCH, CAL), these plant samples identified and listed here alphabetically.

\section{LIST OF PLANT SPECIES}

1. Anisochilus carnosus (L.) Wall. ex Benth.

Fl. \& Fr.: Sept. - Jan.

Distribution: Alwar (Kankwari forest); Bhilwara (Bijalia); Jaipur (Ramgarh); Kota (Darah); Sirohi (Mount Abu); Tonk (Toda Rai Singh Forest).

Specimen examined: Todgarh-Raoli wildlife sanctuary, Bijajiguda Range, Aasan, 03-Sep-18, $25^{\circ} 57.117^{\prime} \mathrm{N} \& 4^{\circ} 07.938^{\prime} \mathrm{E}, 442 \mathrm{~m}$, C.S. Purohit 33563.

2. Anisomeles indica (L.) O. Kuntze

Fl. \& Fr.: Sept. - Jan.

Distribution: Ajmer; Alwar (Kankwari forest); Banswara (Lasora); Barmer (Haldeshwar mahadev); Sirohi (Mount Abu); Tonk (Toda Rai Singh R.F.).

Specimen examined: Todgarh-Raoli wildlife sanctuary, Raoli Range, Ronda (Deval-Fatehgarh), 12 Nov. 2017, 2548.465'N \& 7359.562'E, 546m, C.S. Purohit 33328.

3. Anisomeles malabarica (L.) R.Br. ex Sims.

Fl. \& Fr.: Sept. - Jan.
Distribution: Jaipur; Udaipur.

Specimen examined: Todgarh-Raoli wildlife sanctuary, Raoli Range, Kabradata, 10 Nov. 2017, $25^{\circ} 42.736$ ' N \& 7355.517'E, 445m, C.S. Purohit 33241; Raoli Range, Kabradata, 10 Nov. 2017, $25^{\circ}$ $42.736^{\prime} \mathrm{N} \& 7^{\circ} 55.517^{\prime} \mathrm{E}, 445 \mathrm{~m}$, C.S. Purohit 33242.

4. Hyptis suaveolens (L.) Poit.

Fl. \& Fr.: Almost throughout the year.

Distribution: Kota (Chambal dam).

Specimen examined: Todgarh-Raoli wildlife sanctuary, Raoli Range, Gafa village, 15Nov.2017, 2549.918'N, 7359.617'E, 549m, C.S. Purohit 33397; Bhim Range, Mayali mata temple, 26-Nov-17, 2527.635'N, 7345.348'E, 419m, C.S. Purohit 33476;

5. Lavandula bipinnata (Roth) Kuntze

Fl. \& Fr.: Oct. - Jan.

Distribution: Ajmer; Banswara (Jordha); Barmer (Haldeshwar); Chittorgarh (Bassi); Pali (Kalia pahar); Sirohi (Mount Abu).

Specimen examined: Todgarh-Raoli wildlife sanctuary, Raoli Range, Mangad ji maharaj temple, 18-Nov-17, $25^{\circ} 48.604^{\prime} \mathrm{N} \& 7^{\circ} 59.148^{\prime} \mathrm{E}$, 853m, C.S. Purohit 33430; Bhim Range, Gauri dham-Bagana, 23 Nov. 2017, 25³0.818'N \& $73^{\circ} 49.553^{\prime} \mathrm{E}, 551 \mathrm{~m}$, C.S. Purohit 33460;

6. Leucas aspera (Willd.) Link

Fl. \& Fr.: Most part of the year.

Distribution: Bikaner (Kolayat, Gharsisar); Bundi (Kalakhet); Jaipur; Sirohi.

Specimen examined: Todgarh-Raoli wildlife sanctuary, Raoli Range, Jhamuda, 27-Jul-16, $25^{\circ} 43.633^{\prime} \mathrm{N} \& 7^{\circ} 54.747 ' \mathrm{E}, 385 \mathrm{~m}$, C.S. Purohit 32838; Bijajiguda Range, Kot-Kirana, 13 Nov. 2017, $25^{\circ} 51.770^{\prime} \mathrm{N} \& 74^{\circ} 06.174$ 'E, 518m, C.S. Purohit 33336.

7. Leucas zeylanica (L.) R.Br.

Fl. \& Fr.: Aug. - Nov.

Distribution: Banswara (Shergarh); Sirohi (Mount Abu). 
Specimen examined: Todgarh-Raoli wildlife sanctuary, Bijajiguda Range, Aasan, 07 Aug. 2016, $25^{\circ} 57.117^{\prime} \mathrm{N} \& 7^{\circ} 07.938^{\prime} \mathrm{E}, 442 \mathrm{~m}$, C.S. Purohit 33112.

8. Nepeta bombaiensis Dal. \& Gibs.

Fl. \& Fr.: Oct. - Jan.

Distribution: Ajmer; Sirohi (Mount Abu).

Specimen examined: Todgarh-Raoli wildlife sanctuary, Raoli Range, Kabradata, 10 Nov. 2017, $25^{\circ} 42.736^{\prime} \mathrm{N} \& 7^{\circ} 55.517$ 'E, 445m, C.S. Purohit 33250; Raoli Range, Kabradata, 10 Nov. 2017, $25^{\circ}$ $42.736^{\prime} \mathrm{N} \& 7^{\circ} 55.517^{\prime} \mathrm{E}, 445 \mathrm{~m}$, C.S. Purohit 33261.

9. Ocimum basilicum L. var. basilicum

Fl. \& Fr.: Throughout the year.

Distribution: Ajmer (Beawar); Bharatpur (Chautali village); Bikaner (Beechhwal); Dungarpur (Range forest office); Ganganagar (24 P.S. Raisingh Nagar); Jaisalmer (Mahapalika garden, Pokaran); Jhalawar; Jodhpur (Kailana, Machiya Biological Park); Nagaur (College road, Nagaur).

Specimen examined: Todgarh-Raoli wildlife sanctuary, Bijajiguda Range, Khanda Bhaga, 01Aug-16, $25^{\circ} 53.382^{\prime} \mathrm{N} \& 74^{\circ} 04.899^{\prime} \mathrm{E}, 507 \mathrm{~m}$, C.S. Purohit 32972.

10. Ocimum basilicum L. var. pilosum (Willd.) Bentham

Fl. \& Fr.: July - Sept.

Distribution: Todgarh-Raoli wildlife sanctuary (Aasan).

Specimen examined: Todgarh-Raoli wildlife sanctuary, Bijajiguda Range, Taheshwar temple, 29-Jul.-16, 2549.954'N \& 7356.474'E, 426m, C.S.

Purohit 32913.

11. Ocimum americanum L.

Fl. \& Fr.: Throughout the year.

Distribution: Ajmer (Panchkund); Alwar (Balafort); Barmer (Haldeshwar Mahadev R.F.); Bikaner (Near 682 Head); Dungarpur (Ratanpur);
Jhalawar (Bijliya Bhadak); Nagaur (College road, Nagaur); Pali (Sardhana); Sirohi (Mount Abu).

Specimen examined: Todgarh-Raoli wildlife sanctuary, Bijajiguda Range, Taheshwar mahadev temple, 29-Jul-16, 2549.954' $\mathrm{N} \& 73^{\circ} 56.474$ 'E, 426m, C.S. Purohit 32913.

12. Ocimum filamentosum Forssk. Fl. Aegypt.-Arab. 108. 1775.

Fl. \& Fr.: Aug. - Nov.

Distribution: Todgarh-Raoli wildlife sanctuary (Aasan).

Specimen examined: Todgarh-Raoli wildlife sanctuary, Bijajiguda Range, Aasan, 03-Sep-18, $25^{\circ} 57.117^{\prime} \mathrm{N} \& 7^{\circ} 07.938^{\prime} \mathrm{E}, 442 \mathrm{~m}$, C.S. Purohit 33575.

13. Orthosiphon aristatus (Blume) Miq.

Fl. \& Fr.: Aug. - Nov.

Distribution: Todgarh-Raoli wildlife sanctuary (Aasan).

Specimen examined: Todgarh-Raoli wildlife sanctuary, Bijajiguda Range, Aasan, 06-Aug-16, $25^{\circ}$ 57.117'N \& 7407.938'E, 442m, C.S. Purohit 33091.

14. Orthosiphon pallidus Benth.

Fl. \& Fr.: Aug. - Nov.

Distribution: Ajmer (Todgarh); Banswara (Ghatol); Chittorgarh (Bassi); Jhalawar (Bijliya Bhadak); Tonk (Kotri village).

Specimen examined: Todgarh-Raoli wildlife sanctuary, Bhim Range, Putia Kheda, 02-Aug-16, $25^{\circ} 38.929^{\prime} \mathrm{N} \& 74^{\circ} 00.443^{\prime} \mathrm{E}, 636 \mathrm{~m}$, C.S. Purohit 33012; Raoli Range, Kabradata, 10 Nov. 2017, $25^{\circ}$ $42.736^{\prime} \mathrm{N} \& 7^{\circ} 55.517 ' \mathrm{E}, 445 \mathrm{~m}$, C.S. Purohit 33268;

15. Salvia aegyptiaca L.

Fl. \& Fr.: December - March.

Distribution: Ajmer; Bharatpur (Lahasar village); Bikaner (Kolayat); Jaisalmer; Jodhpur (Keru village); Pali (Gundoj hills); Udaipur (Sajangarh).

Specimen examined: Todgarh-Raoli wildlife sanctuary, Bijajiguda Range, Taheshwar Mahadev, 
29-Jul-16, 2549.954' N \& 7356.474'E, 426m, C.S. Purohit 32906; Raoli Range, Katarghati, 30-Jul-16, $25^{\circ} 43.885^{\prime} \mathrm{N} \& 73^{\circ} 59.160^{\prime} \mathrm{E}, 674 \mathrm{~m}$, C.S. Purohit 32929.

\section{Salvia santolinaefolia Boiss.}

Fl. \& Fr.: Aug. - Feb.

Distribution: Barmer (Luni river, balotra); Bundi (Hindoli); Jodhpur (Mandore); Pali (Jawai dam).

Specimen examined: Todgarh-Raoli wildlife sanctuary, Bhim Range, Goramghat, Rajsamand, 05-Aug-16, 2538.491'N \& 7352.022'E, 488m, C.S. Purohit 33060.

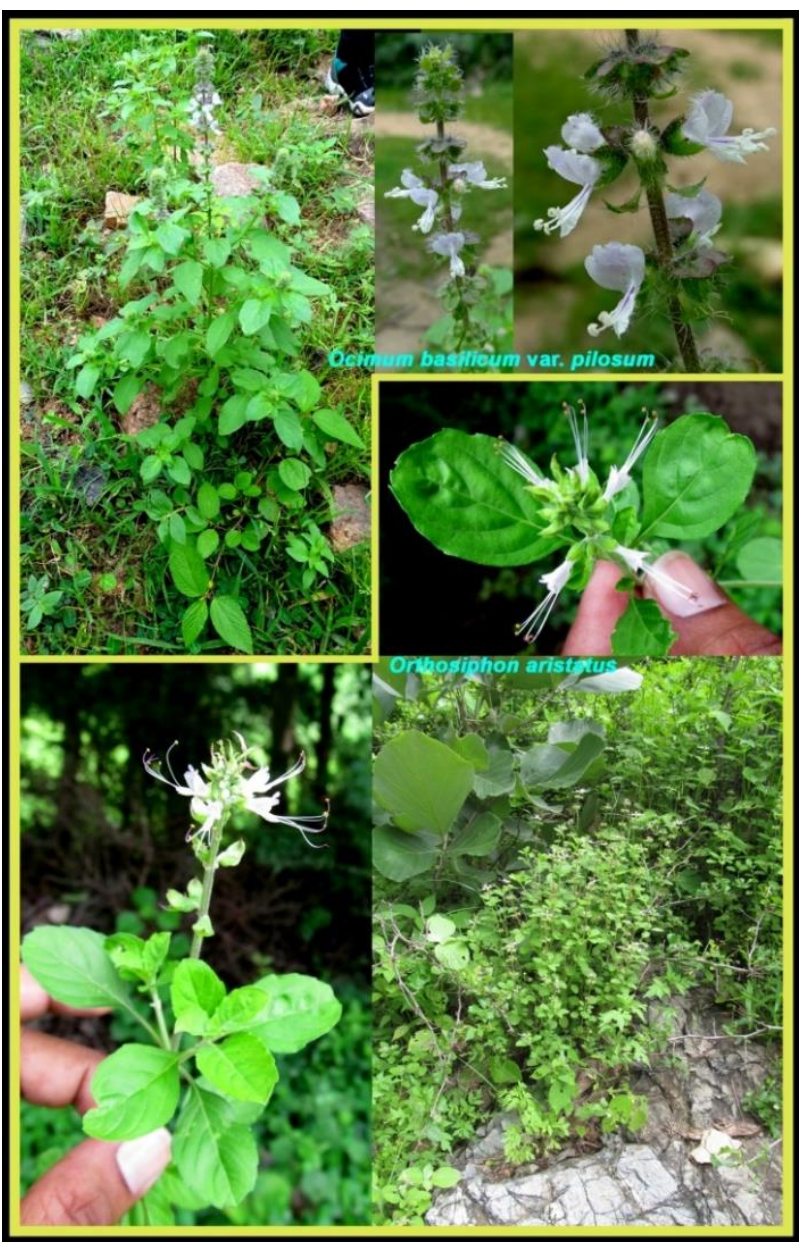

Fig. 1: Species addition for flora of Rajasthan

\section{RESULT AND DISCUSSION}

Present status of family Lamiaceae in Todgarh-Raoli wildlife sanctuary and their comparision with other floras are in following points.

\section{[1]. STATISTICAL ANALYSIS OF FAMILY LAMIACEAE:}

The present work enumerates 16 species, belonging to 9 genera under family Lamiaceae (Table-1).

Table. 1: Status of family Lamiaceae in Todgarh-Raoli wls

\begin{tabular}{|c|c|l|c|}
\hline Family Name & $\begin{array}{c}\text { Genus } \\
\text { no. }\end{array}$ & Genus Name & $\begin{array}{c}\text { Species } \\
\text { no. }\end{array}$ \\
\hline LAMIACEAE & 1 & Anisochilus & 1 \\
\cline { 2 - 4 } & 2 & Anisomeles & 2 \\
\cline { 2 - 4 } & 3 & Hyptis & 1 \\
\cline { 2 - 4 } & 4 & Lavandula & 1 \\
\hline & 5 & Leucas & 2 \\
\hline & 6 & Nepeta & 1 \\
\hline 7 & Ocimum & 4 \\
\hline & 8 & Orthosiphon & 2 \\
\cline { 2 - 4 } & 9 & Salvia & 2 \\
\hline
\end{tabular}

Table-2. Genera of Lamiaceae in this area and compare with other floras

\begin{tabular}{|l|c|c|c|c|}
\hline \multirow{2}{*}{ Genus } & \multicolumn{4}{|c|}{ No. of species and varieties } \\
\cline { 2 - 5 } & $(1)$ & $(2)$ & $(3)$ & $(4)$ \\
\hline Anisochilus & 1 & - & 1 & 2 \\
\hline Anisomeles & 2 & - & 1 & 2 \\
\hline Hyptis & 1 & - & 1 & 1 \\
\hline Lavandula & 1 & - & 2 & 2 \\
\hline Leucas & 2 & 2 & 6 & 14 \\
\hline Nepeta & 1 & - & 2 & 2 \\
\hline Ocimum & 4 & 3 & 4 & 4 \\
\hline Orthosiphon & 2 & - & 1 & 2 \\
\hline Salvia & 2 & - & 2 & 3 \\
\hline
\end{tabular}

(1): Todgarh-Raoli wls. (Purohit, 2020); (2): Todgarh-Raoli wls (Kanther, 2019); (3): Aravalli range (Otaghvari et. al. 2015); (4): Flora of Rajasthan (Shetty \& Singh, 1991);

The family Lamiaceae maintains $12^{\mathrm{h}}$ number highest diversity among angiosperms containing 16 species under 9 genera. The four genera represented by single 
species i.e. Anisochilus, Hyptis, Lavandula, Nepeta (Table-2).

\section{[2]. ADDITION FOR FLORA OF RAJASTHAN}

During the coarse of field exploration of protected area of Todgarh-Raoli wildlife sanctuary in July Aug. 2016, first author demarcated and collected small population of two individuals (1) first population of individuals belonging to genus Ocimum from Taheshwar temple (Bijaguda Range) with retrose hairs on internodes, fruiting calyx up to $5 \mathrm{~mm}$ long and (2) secod population of individuals belonging to genus Orthisiphon from Aasan (Bijaguda Range) with ovate to rhombic leaves with coarsely toothed margins, campanulate-curved calys, white corolla with exerted stamens, filaments $3 \mathrm{~cm}$ long. After critical study, scrutiny of literature (Hooker, 1885; Blatter \& Hallberg, 1920; Mukerjee, 1940; Sharma \& Tiagi, 1979; Bhandari, 1990; Shetty \& Singh, 1991; Singh, 1998; Singh, 2001; Tiagi \& Aery, 2007; Otaghvari et al., 2015) and herbaria (BSJO, BSA, RUBL, JAC, BLAT, DCH, CAL, K), it is identified first population as Ocimum basilicum L. var. pilosum (Willd.) Bentham and second population Orthosiphon aristatus (Blume) Miq. It is first time report and addition for flora of Rajasthan [Fig. 1, Fig. 2, Fig. 3].

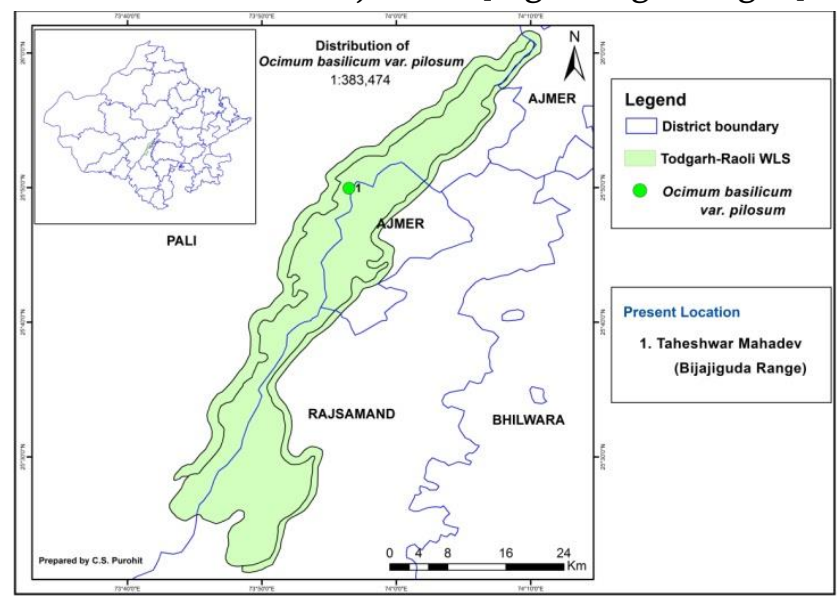

Fig. 2 Location map of Ocimum basilicum L. var. pilosum (Willd.) Bentham

\section{[3]. ADDITION FOR FLORA OF ARAVALLI RANGE:}

In comparision with Lamiaceae of Aravalli range, 75\% genera of aravalli range represent in Todgarh-Raoli widllife sanctuary (table-3), whereas $66.67 \%$ species and variety of aravalli range represent in this sanctuary. In comparision with Rajasthan flora, $60 \%$ genera and $37.21 \%$ species, var. of family Lamiaceae represents in this Sanctuary.

Otaghvari et al. (2015) have done extensive work on flora of Aravalli range and reported 24 species belonging to 12 genera under family Lamiaceae (Table3). In this paper, five plant species i.e. Anisomeles malabarica (L.) R.Br. ex Sims.; Ocimum basilicum L. var. pilosum (Willd.) Bentham (Fig. 2); Ocimum filamentosum Forssk. (Fig. 4); Orthosiphon aristatus (Blume) Miq. (Fig. 3); Salvia aegyptiaca L. are first time report from Aravalli range and addition for flora of Aravalli range.

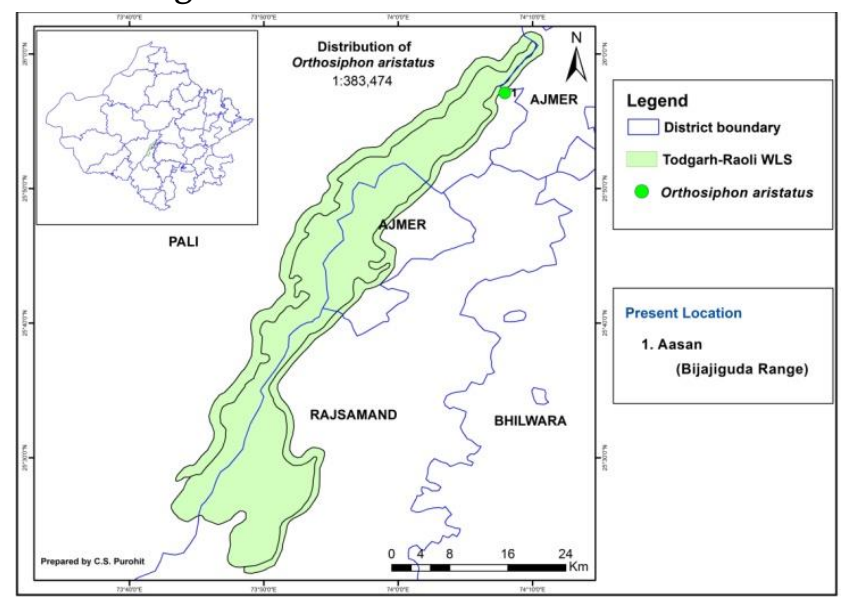

Fig. 3 Location map of Orthosiphon aristatus (Blume) Miq.

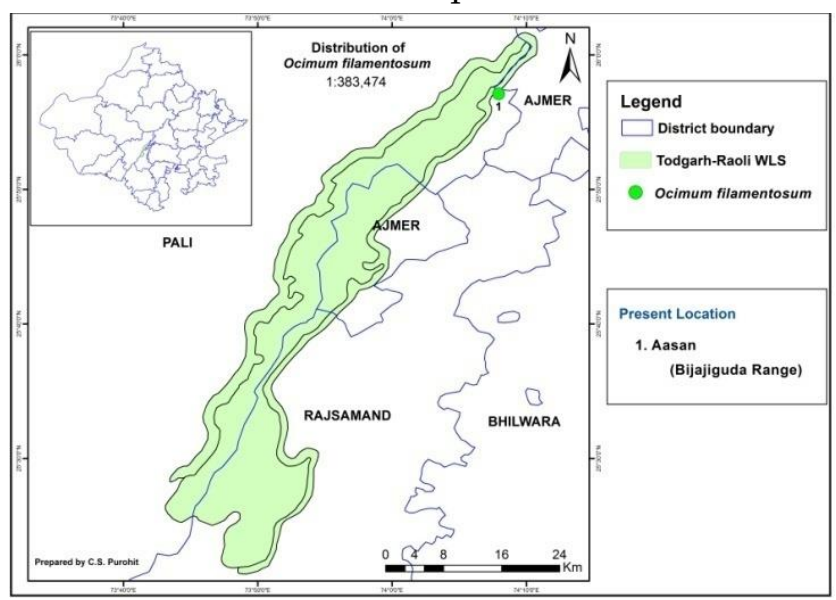


Fig. 4 Location map of Ocimum filamentosum Forssk. Table 3. Comparison of Lamiaceae of this sanctuary with previous publications.

\begin{tabular}{|c|c|c|c|c|}
\hline Family & $(1)$ & $(2)$ & $(3)$ & $(4)$ \\
\hline Lamiaceae & & & & \\
\hline Genus & 9 & 3 & 12 & 15 \\
\hline $\begin{array}{c}\text { Species \& } \\
\text { variety }\end{array}$ & 16 & 7 & 24 & 43 \\
\hline
\end{tabular}

(1): Todgarh-Raoli wls. (Purohit, 2020); (2): Todgarh-Raoli wls (Kanther, 2019); (3): Aravalli range (Otaghvari et. al. 2015); (4): Flora of Rajasthan (Shetty \& Singh, 1991);

\section{[4]. ADDITION FOR FLORA OF TODGARH-RAOLI WILDLIFE SANCTUARY}

Kanther (2019) have done extensive work on Flora of Todgarh-Raoli wildlife sanctuary and reported 7 species belonging to 3 genera under family Lamiaceae (table-3). In this paper, seven genera Anisochilus, Anisomeles, Hyptis, Lavandula, Nepeta, Orthosiphon and Salvia are first time report and generic addition for flora of Todgarh-Raoli wildlife sanctuary (table-2) and 14 plant species i.e. Anisochilus carnosus (L.) Wall. ex Benth. var. carnosus; Anisomeles indica (L.) O. Kuntze; Anisomeles malabarica (L.) R.Br. ex Sims.; Hyptis suaveolens (L.) Poit.; Lavandula bipinnata (Roth) Kuntze; Leucas aspera (Willd.) Link; Leucas zeylanica (L.) R.Br.; Nepeta bombaiensis Dal. \& Gibs.; Ocimum basilicum L. var. pilosum (Willd.) Bentham; Ocimum filamentosum Forssk.; Orthosiphon aristatus (Blume) Miq.; Orthosiphon pallidus Benth.; Salvia aegyptiaca L.; Salvia santolinaefolia Boiss. are first time report and addition for flora of Todgarh-Raoli wildlife sanctuary [Fig. 5].

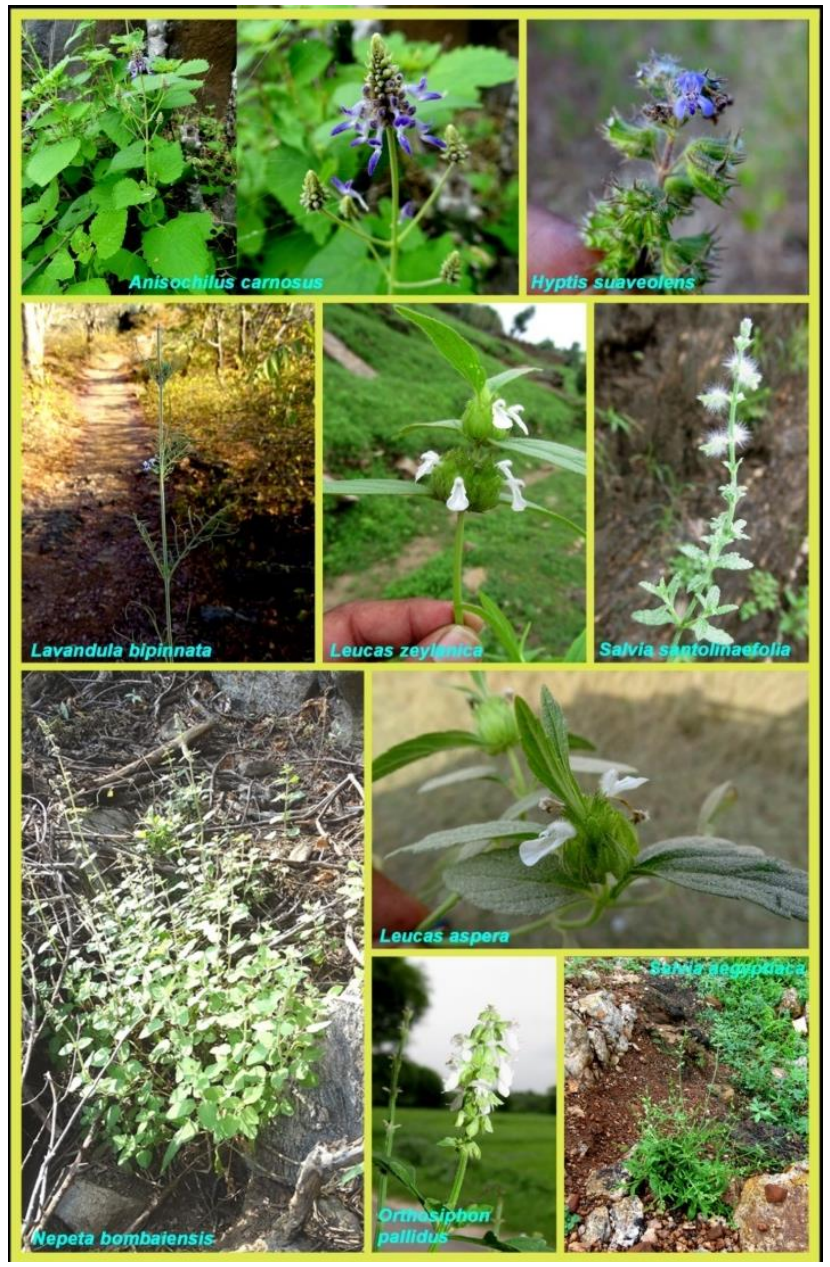

Fig. 5: Species addition for flora of Todgarh-Raoli wls

\section{CONCLUSION}

Present paper deals with 16 species belonging to 9 genera of family Lamiaceae collected from this sanctuary. Out of these, two species Ocimum basilicum L. var. pilosum (Willd.) Bentham and Orthosiphon aristatus (Blume) Miq. are reported first time and addition for flora of Rajasthan. Five species are reported first time and addition for flora of Aravalli range. Seven genera Anisochilus, Anisomeles, Hyptis, Lavandula, Nepeta, Orthosiphon and Salvia are first time report and generic addition for flora of Todgarh-Raoli wildlife sanctuary and 14 plant species are addition for flora of Todgarh-Raoli wildlife sanctuary. 


\section{ACKNOWLEDGEMENT}

Authors are grateful to the Director, Botanical Survey of India, Kolkata and HOO, BSI-AZRC Jodhpur for facilities and encouragements. Thanks are due to Sh. Bhoma Ram (Field Assistant) and Sh. Ranjeet (M.T.S.), Botanical Survey of India, Arid Zone Regional Centre, Jodhpur, for assistance during field survey. Thanks is also extend to the State Forest Department, Rajasthan and Forest staff, Todgarh-Raoli wildlife sanctuary for extending their co-operation during survey \& exploration.

\section{REFERENCES}

[1]. Bhandari M.M. 1990. Flora of the Indian Desert. Scientific Publishers, Jodhpur (Revised Edition).

[2]. Blatter E. \& F. Hallberg 1920. The flora of the Indian desert (Jodhpur and Jaisalmer). Journal of the Bombay Natural History Society, 26 (4): 971.

[3]. Hooker J.D. 1885. Labiatae, The Flora of British India 4: 680 - 691.

[4]. Kanther R.P. 2019. Dominant flora of TodgarhRaoli wildlife sanctuary, Rajasthan, India. J. Indian Bot. Soc. 98(1-2): 59 - 70.

[5]. Mukerjee S.K. 1940. A revision of Lamiaceae of Indian Empire. Records of the Botanical Survey of India 14: $1-62$.

[6]. Otaghvari A.M., S.R. Yadav, S.N. Raina and P.L. Uniyal 2015. Vegetational wealth of Aravalli Rajasthan. Scientific Publishers, Jodhpur.

[7]. Purohit C.S. 2020. Flora of Todgarh-Raoli wildlife sanctuary with GIS mapping of EET species. Project Report submitted to Director, BSI, Kolkata.

[8]. Sharma S. and B. Tiagi 1979. Flora of North-East Rajasthan. 265 - 271. New Delhi.

[9]. Singh V. 1998. Critical taxonomic notes on Leucas R.Br. Journ. Taxon. Bot. 22(2): 388.
[10]. Singh V. 2001. Monograph on Indian Leucas R.Br. (Dronapushpi) Lamiaceae. In: Journ. Econ. Taxon. Bot. Add. Ser. 20. Scientific Publishers (India), Jodhpur.

[11]. Tiagi Y. D. \& N. C. Aery 2007. Flora of Rajasthan (south \& south-east region). Himanshu Publications, Udaipur, India.

\section{Cite this article as :}

C. S. Purohit, Komal Jain, Merushikha, "A note on Family Lamiaceae in Todgarh-Raoli Wildlife Sanctuary, with Addition of Two Species for Flora of Rajasthan", International Journal of Scientific Research in Science and Technology (IJSRST), Online ISSN : 2395-602X, Print ISSN : 2395-6011, Volume 7 Issue 2, pp. 438-444, March-April 2020. Available at doi : https://doi.org/10.32628/IJSRST207278 Journal URL : http://ijsrst.com/IJSRST207278 